\title{
Si 添加高炭素鋼の恒温変態挙動に及ぼすボロン添加の影響
}

\author{
真鍋 敏之 ${ }^{1) *} \cdot{\text { 山㟝 } \text { 真吾 }^{1)} \cdot \text { 西田 世紀 }}^{2)} \cdot$ 菅原 寿晴 ${ }^{3)}$
}

Effect of Boron Addition for on Time Temperature Transformation Behavior in Si Added High Carbon Steels

Toshiyuki Manabe, Shingo Yamasaki, Seiki Nishida and Toshiharu Sugawara

\begin{abstract}
Synopsis : In high carbon steel, TTT nose temperature rises and upper baninte becomes easy to be formed with quantity of Si addition. Generation of upper bainite is reduced by boron addition. In this study, the influence of boron addition on isothermal transformation behavior in Si-added high carbon steel was clarified. By boron addition, lamellar spacing and growth rate of pearlite doesn't change, but the nucleation of pealite is reduced. But nucleation of pearlite is promoted when $\mathrm{Fe}_{23}(\mathrm{C}, \mathrm{B})_{6}$ precipitates. In the Si-added high carbon steel, upper bainite is often formed with the generated ferrite on prior austenite grain boundary. It is inferred that boron reduces ferrite generation in grain boundary which causes upper bainite formation. It is confirmed that effective existence state of boron is grain boundary segregation.
\end{abstract}

Key words: high carbon steel; boron; isothermal transformation; silicon; bainite.

\section{1. 緒言}

橋梁のメインケーブルや, 高強度 PC（プレストレスト コンクリート) ストランド，タイヤに使用されるスチール コードなど, 伸線加工が施されて使用される材料の素材に は, 加工硬化能の高い ${ }^{1)}$ パーライト組織となる高炭素鋼線 材が使用される。これらの高強度化には, 加工方法に合わ せた合金元素の添加が行われる。例えば，スチールコード は伸線加工ひずみ量が大きく, ラメラー間隔の微細化が有 効であるため $\mathrm{Cr}$ が添加される ${ }^{2)}$ 。また, 橋梁のメインケー ブル用のワイヤは伸線後に溶融亜鉛めっきが施されるた め, 伸線パーライト組織のセメンタイトの球状化抑制のた め, Siが添加される ${ }^{3)}$ 。世界最長の吊り橋である明石海峡 大橋では, Siを $0.9 \%$ 添加することによって, 従来よりもワ イヤ強度を $200 \mathrm{MPa}$ 向上することが可能となった ${ }^{4}$ 。

一方, これらの合金元素の添加は従来の熱処理条件から 最適な条件への変更を必要とすることとなる。パーライト 組織の熱処理には一般的にパテンティングと呼ばれるオー ステナイトに溶体化後, $500 \sim 600^{\circ} \mathrm{C}$ 保持する恒温変態処 理が施される。Crの添加はセメンタイトの未溶体化の可能 性が高まり, Siの添加は恒温変態曲線 (TTT) のノーズ温 度が高温化することで最適な変態温度が上昇する。後者の ノーズを下回った温度で熱処理を行った場合，一般的には 上部ベイナイトが生成する。実際の線材のパテンティング
処理では，オーステナイト域に加熱後，鉛などの溶媒に浸 漬するため, 線材の表層と中心部では溶媒温度までの冷却 速度が異なり, 表層にのみ上部べイナイトが生成すること が多い。この組織はセメンタイトが粗大に分散した組織で あり, パーライトよりも軟質であり, 加工硬化能も低く, 更にワイヤの延性評価指標であるねじり特性を劣化させ る5)。ねじり特性は, ワイヤをねじった際の破断までのね じり回数と破面形態で評価される。ワイヤの表層に上部べ イナイト組織が存在すると, ねじり開始直後に縦割れ（デ ラミネーション) が発生し易くなる5) ことが報告されてい る。

著者らは, Siを添加した高炭素鋼において, ボロンを添 加することにより上部ベイナイト組織が低減されることを 報告している ${ }^{6)}$ 。低炭素鋼においては, ボロンを添加する ことで, 焼入れ性が著しく向上することが良く知られてい るが, 高炭素鋼のボロンの添加については, 焼入れ性に対 しては効果が無い ${ }^{7)}$, パーライト組織中の第二相フェライ トの生成を抑制する ${ }^{8)}$, 中炭素鋼では延性を向上させるが, 高炭素鋼では低下させる ${ }^{9,10)}$ などの報告例があるが, 恒温 変態でのボロンの挙動に着目した報告例は少ない。本研究 では, Siを添加した高炭素鋼における, パテンティングの 際のボロンの挙動に着目し, その挙動を明らかとした。

2018年5月24日受付２018年8月20日受理２018年10月18日J-STAGE早期公開 (Received on May 24, 2018; Accepted on Aug. 20, 2018；J-STAGE Advance published on Oct. 18, 2018)

1）新日鐵住金 (株) 技術開発本部棒線研究部（Bar and Wire Rod Research Lab., Steel Research Laboratories, Nippon Steel \& Sumitomo Metal Corporation, 20-1 Shintomi Futtsu Chiba 293-8511)

2）新日鐵住金 (株) 本社知的財産部 (Intellectual Property Department, Head Office, Nippon Steel \& Sumitomo Metal Corporation)

3）日鉄住金テクノロジー（株）君津事業所 (Kimitsu Division, Nippon Steel \& Sumikin Technology Co., Ltd.)

* Corresponding author : E-mail : manabe.re4.toshiyuki@jp.nssmc.com

DOI : https://doi.org/10.2355/tetsutohagane.TETSU-2018-055 


\section{2. 実験方法}

供試鋼は，真空溶解により溶製した。0.70 mass\%C-1.0 mass $\% \mathrm{Si}-1.0$ mass\%Mn 鋼をべースに, Tiを添加したもの, Ti とBを添加したもの, 更に 0.87 mass\%C-0.90 mass\%Si-0.7 mass\%Mn鋼をべースに, ベース鋼ままと, Bを添加したも の, Ti と B を添加しNを TiNとして固定したものの計 5 鋼 種を使用した。それぞれの化学成分を Table 1 に示す。鋼材 $\mathrm{A}, \mathrm{B}$ はインゴットを均熱処理後に熱間鍛造を行い, パテン ティング後に伸線加工を施したものを，鋼材 $\mathrm{C} 〜 \mathrm{E}$ はイン ゴットを熱間鍛造にて 122 角のビレットに成型し, 熱間圧 延により $12 \mathrm{~mm}$ の線材としたものを使用した。

先ず, 鋼種 $\mathrm{A}, \mathrm{B}$ からフォーマスタ試験片を切り出し, 全 自動変態測定記録測定装置 (フォーマスタ試験装置) にて, $950^{\circ} \mathrm{C}$ に加熱後 $180 \mathrm{~s}$ 保持を行い, 500 $675^{\circ} \mathrm{C}$ の温度域で変 態終了まで保持を行いへリウムガスにて室温まで急冷し， TTT曲線を採取した。次にTTTノーズ以上の温度でのパー ライト変態に及ぼすボロンの影響を調査するため, ノーズ 以上の変態温度で変態中にヘリウムガスにて急冷を行い, 組織を凍結した。その後，ピクラール溶液によりエッチン グを行い, 電界放出型走査電子顕微鏡 (FE-SEM) で組織 観察を行い, パーライトノジュールの成長速度と, パーラ イトの生成核を確認した。また, パーライトブロックは電 子線後方散乱回折装置 (EBSD) を用いて角度差 $9^{\circ}$ で区切 られる粒界と定義し ${ }^{11)}$, 切片法により粒径を算出した。な お，測定にはパーライトブロック粒が 30 個以上含まれる よう, パーライト変態温度条件によって領域を変えて測定 した。TTTノーズ以下の温度での変態についても, $525^{\circ} \mathrm{C}$ での変態途中で急冷を行い, 組織を凍結した。その後FESEM, EBSDによる観察を行い, 上部べイナイトの生成挙 動とボロンの影響を検討した。また, 有効なボロンの存在 状態を検証した。本供試鋼でのボロンの存在状態は粒界偏

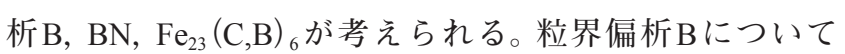
は, 鋼種 $\mathrm{B}$ を用いてアルファ線トラックエッチング (ATE) 法によりボロンの分布を確認した。ATE法は, ボロンの原 子核と中性子が核反応によりリチウム核とへリウム核と なり，このへリウム核と観察面に貼り付けられたフィルム との反応を利用している。ATE像の観察手順は以下の方法 で行った。先ず観察面にアセチルセルロースフィルムに酢 酸メチル液を塗布して貼り付けた。次に日本原子力研究所

Table 1. Chemical Composition (mass\%, *mass ppm).

\begin{tabular}{ccccccccc}
\hline Steel & $\mathrm{C}$ & $\mathrm{Si}$ & $\mathrm{Mn}$ & $\mathrm{P}$ & $\mathrm{S}$ & $\mathrm{Ti}$ & $\mathrm{B} *$ & $\mathrm{~N}^{*}$ \\
\hline $\mathrm{A}$ & 0.70 & 1.01 & 1.01 & 0.003 & 0.001 & 0.013 & - & 34 \\
$\mathrm{~B}$ & 0.70 & 1.01 & 1.00 & 0.003 & 0.001 & 0.013 & 11 & 34 \\
$\mathrm{C}$ & 0.86 & 0.90 & 0.72 & 0.008 & 0.008 & - & - & 44 \\
$\mathrm{D}$ & 0.86 & 0.91 & 0.75 & 0.007 & 0.008 & - & 18 & 43 \\
$\mathrm{E}$ & 0.86 & 0.89 & 0.74 & 0.008 & 0.008 & 0.011 & 20 & 40 \\
\hline
\end{tabular}

の JRR-3にて中性子照射を行い, 照射後のフィルムを $2.5 \mathrm{~N}$ の $\mathrm{NaOH}$ 水溶液にてエッチングを施した。その後, エッチ ング面を金蒸着して光学顕微鏡にて観察を行った。BNの

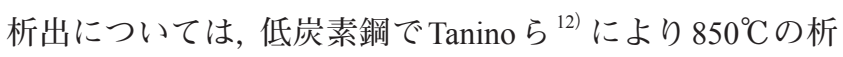
出ノーズが報告されている。一方, $\mathrm{Fe}_{23}(\mathrm{C}, \mathrm{B})_{6}$ の析出につ いては, Grange and Mitchell ${ }^{13)}$, Yamamoto ${ }^{14)}$ により 650 〜 $800^{\circ} \mathrm{C}$ に析出ノーズが報告されている。そこで, 鋼種 $\mathrm{C}$ $\sim \mathrm{E}$ 用いて $1100^{\circ} \mathrm{C} に 180 \mathrm{~s}$ 加熱後, $\mathrm{BN}$ の析出を狙い, 一度 $850^{\circ} \mathrm{C} に 0 \sim 30 \mathrm{~s}$ の保持を行い, $525^{\circ} \mathrm{C}$ で恒温変態させた組 織, あるいは鋼種 $\mathrm{C}, \mathrm{E}$ を用いて $\mathrm{Fe}_{23}(\mathrm{C}, \mathrm{B}){ }_{6}$ の析出を狙い, $950^{\circ} \mathrm{C}$ に $180 \mathrm{~s}$ 加熱後, $675^{\circ} \mathrm{C}$ で $3 \mathrm{~s}$ の保持を行い, $525^{\circ} \mathrm{C}$ で恒 温変態させた組織を観察し, 上部べイナイト組織率を求め ることで有効なボロンの存在状態を確認した。析出物の同 定には200 kV-電解放出型透過電子顕微鏡 (FE-TEM, JEM$2100 \mathrm{~F}$, 日本電子製) とエネルギー分散型X線分光器 (EDS), ならびに電界放出型電子線マイクロアナライザー（EFEPMA）を用いた。なお, 上部べイナイト組織率は, 2000 倍 のFE-SEM写真を 5 枚 (約 $10000 \mu \mathrm{m}^{2}$ の領域) 撮影し, 上部 ベイナイト組織と判断される部分をマーキングして, マー キング部で囲まれる面積分率の平均值とした。

\section{3. 実験結果と考察}

\section{3・1 TTT線図と上部ベイナイト組織率}

Fig.1 1鋼種 A, Bの TTT線図を示す。パーライト変態の ノーズ温度は $625^{\circ} \mathrm{C}$ 程度であることが分かる。また，ノー ズ以下を下回る $600^{\circ} \mathrm{C}$ 以下の温度域での上部べイナイト組 織率を算出し, 鋼種 $\mathrm{A}$ を $500^{\circ} \mathrm{C}$ で恒温変態させた際の上部 ベイナイト組織率と比較した結果をFig.2 に示す。合わせ て $525^{\circ} \mathrm{C}$ における組織観察結果を Fig.3 に示す。ボロン添加 を行った鋼種における恒温変態の特徵は以下の通りであ る。

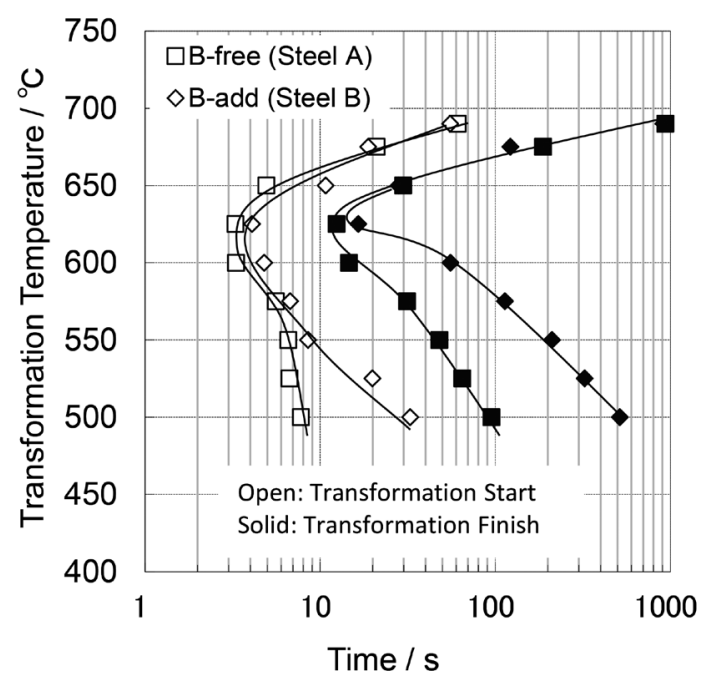

Fig. 1. Time-temperature-transformation diagram. 
・ノーズ温度近傍以下の温度域ではボロン添加により変態 開始, 終了温度が遅延する。

・ノーズ温度を超える温度域 $\left(675^{\circ} \mathrm{C}\right.$ 以上) では, 変態が促 進される。

・ノーズ温度以下の温度域ではベイナイト組織の生成が抑 制される。

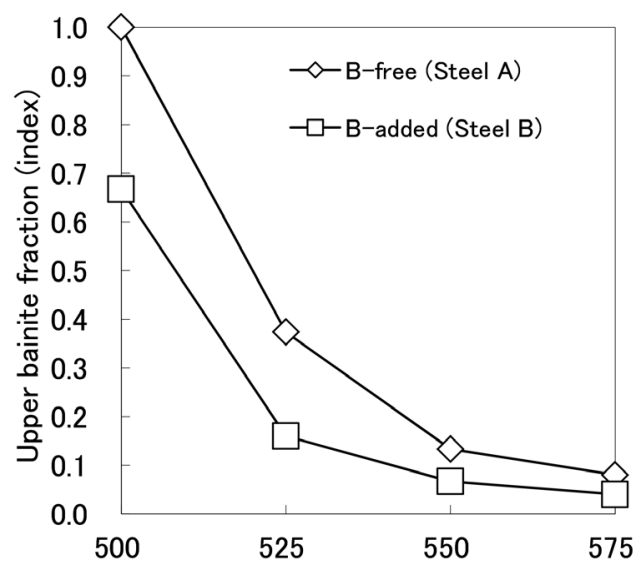

Isothermal transformation temperature $/{ }^{\circ} \mathrm{C}$

Fig. 2. Relationship between Bainite fraction and isothermal transformation temperature.
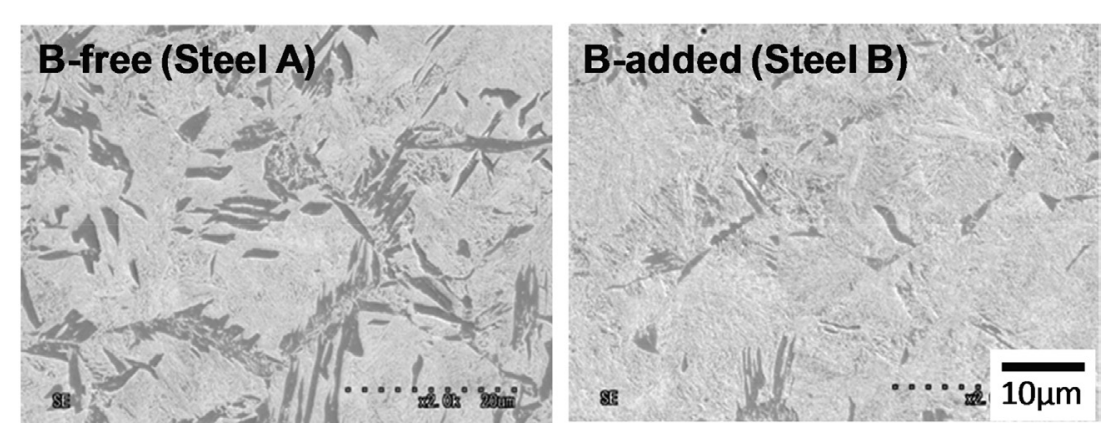

Fig. 3. Microstructure transformed at 525 degrees. (Bright Area: Pearlite, Dark Area: Upper Bainite)

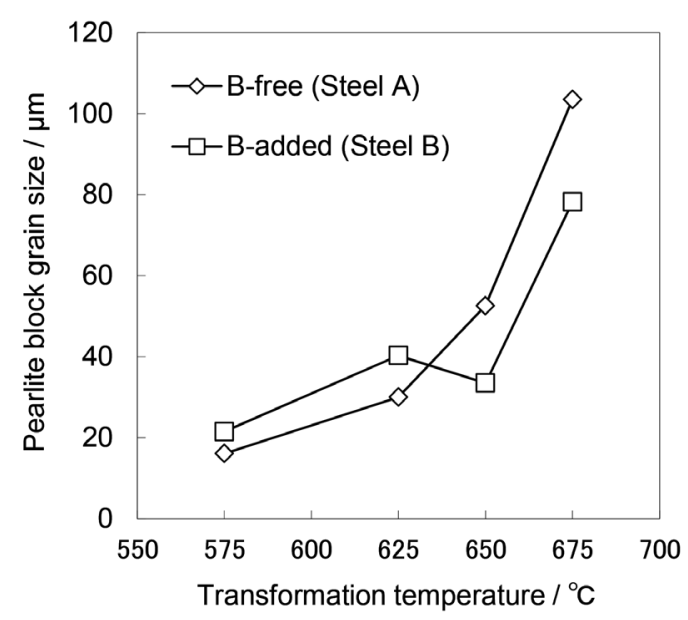

Fig. 4. Relationship between PBS and isothermal transformation temperature.

\section{$3 \cdot 2$ CCTノーズ温度以上でのパーライト変態に及ぼすボロ ンの影響}

Fig.4, Fig.5に鋼種A, Bのノーズ温度近傍以上での各 温度のパーライトブロックサイズ (以下PBS) と最小ラメ ラー間隔をそれぞれ示す。PBSについては, 変態温度の上 昇に伴い，ボロン無添加の鋼種 $\mathrm{A}$ は粗大化する。一方，ボ ロンを添加した鋼種 $\mathrm{B}$ は, 低温では鋼種 $\mathrm{A}$ に対し粗大化 するが，高温になると微細化した。最小ラメラー間隔につ いては, ボロンの有無にかかわらず殆ど変化が見られな

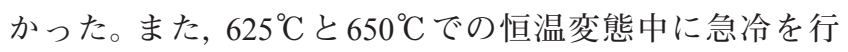
い, 最大パーライトノジュール径の時間変化を調べた結果 をFig.6に示す。パーライトの成長速度である傾きは殆ど 変化しないことから, ボロン有無に関わらずパーライトの

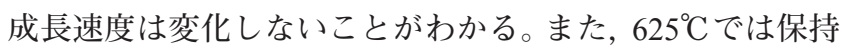
時間と最大ノジュール径がボロン有無に関わらず一致する が，650 Cでは成長速度がほぼ等しいにもかかわらず，同じ 最大ノジュールサイズになる保持時間がボロン添加で短時 間化する。したがって, $625^{\circ} \mathrm{C}$ 以下でボロン添加により PBS が粗大化する理由はパーライト変態の核生成頻度が抑制さ れたためで, $650^{\circ} \mathrm{C}$ 以上でボロン添加により PBSが微細化 する理由はパーライト変態を早める核生成サイトが恒温保 持中に発生，増加したためと考えられる。

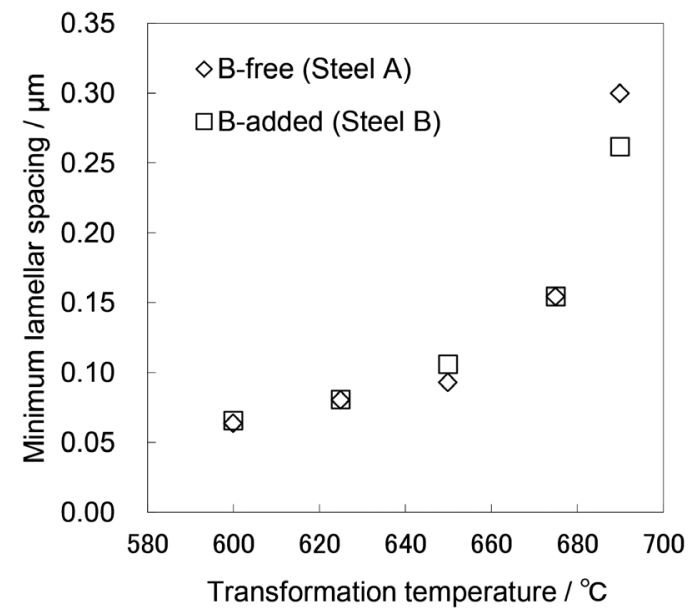

Fig. 5. Relationship between minimum lamellar spacing and isothermal transformation temperature. 
そこで, 高温でのボロン添加によるパーライトの核生成 の変化の要因を明確化するため，ボロン添加した鋼種 $\mathrm{B} に$ 対し，組織観察を行った。Fig.7に各恒温変態温度でパー ライト変態が開始した時点で急冷を行った組織の光学顕 微鏡写真を示す。高温になるほど，未変態の旧オーステナ

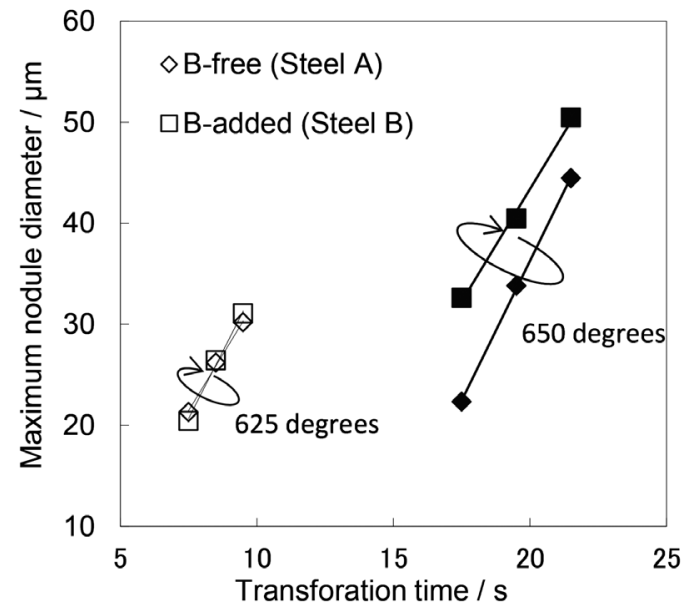

Fig. 6. Relationship between maximum pearlite nodule diameter and isothermal holding time. Slopes on the graph show pearlite growth rates.

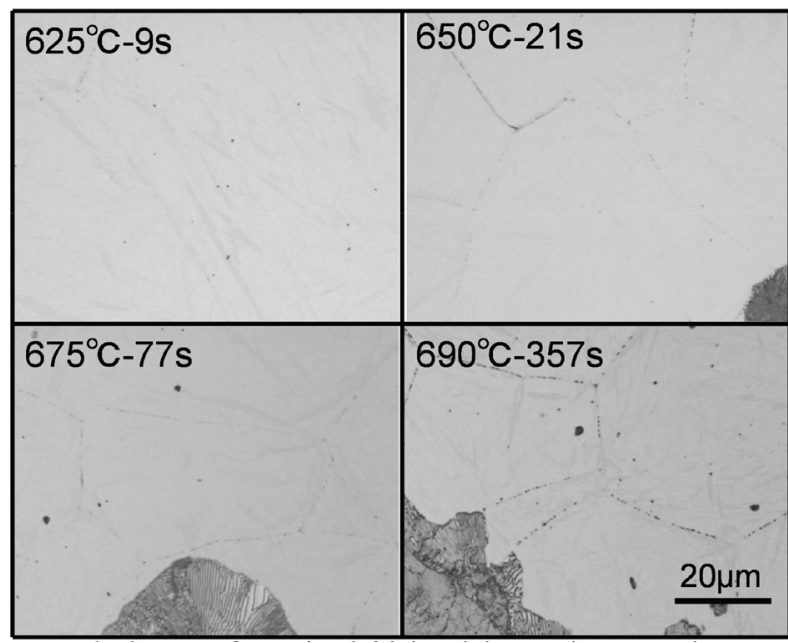

Fig. 7. Microstructure quenched at transformation initial. Bright area is Martensite or retained austenite and dark area is pearlite. Precipitates are observed at prior austenite boundaries. (Steel B)
イト粒界上に析出物が観察された。更に $650^{\circ} \mathrm{C}$ の変態初期 組織をSEMで観察したところ粒界析出物を核にフェライ トが生成している様子が観察された（Fig.8）。粒界析出物 を同定するため, 別途加熱後 $675^{\circ} \mathrm{C}, 3 \mathrm{~s}$ 保定後に急冷を行 い, 組織観察と FE-EPMAによる元素分析を行い, 更に抽 出レプリカ法とTEMにより，析出物を同定した。Fig.9に FE-EPMAの結果を, Fig.10にTEMによる電子線回折の結

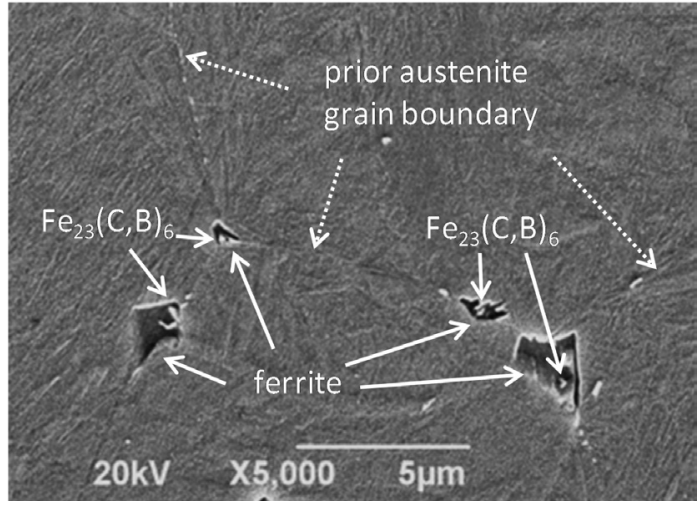

Fig. 8. Initial microstructure transformed at 650 degrees. Ferrite generated next to $\mathrm{Fe}_{23}(\mathrm{C}, \mathrm{B})_{6}$. (Steel $\left.\mathrm{B}\right)$

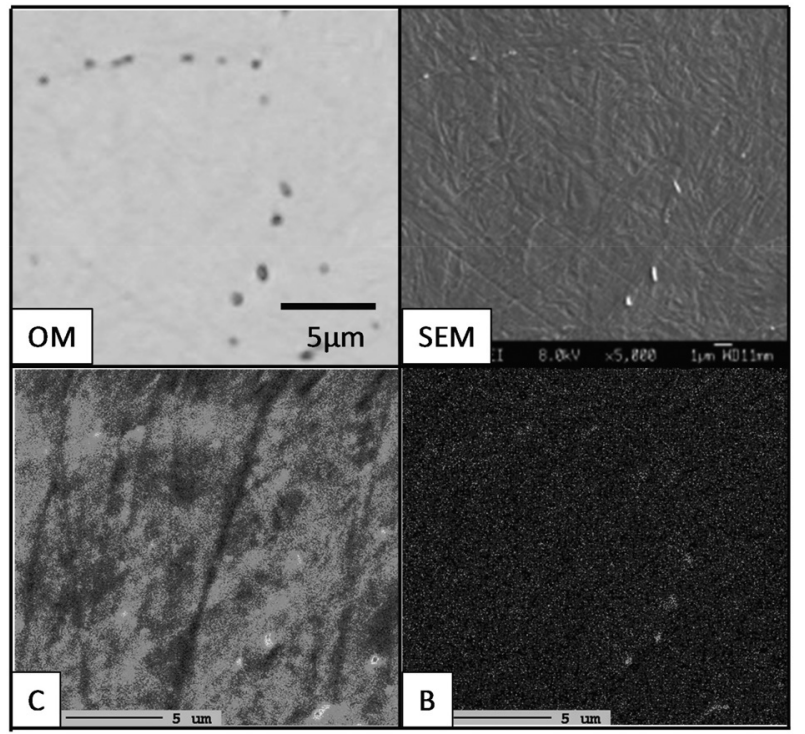

Fig. 9. Elemental map of boron and carbon by FE-EPMA. Precipitates cotained boron and carbon. (Steel B)

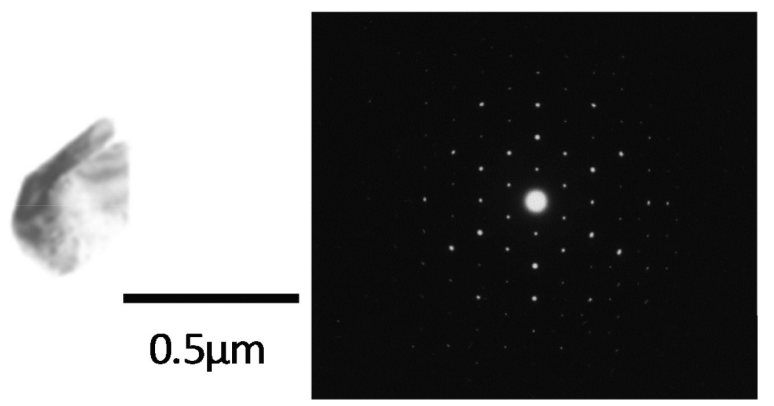

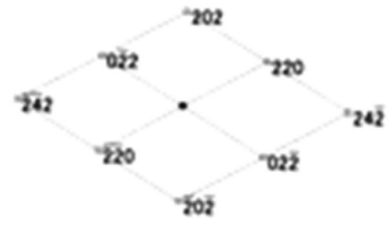

$[1 \overline{1} \overline{1}] \mathrm{Fe}_{23}(\mathrm{C}, \mathrm{B})_{6}$

Fig. 10. TEM image and electron diffraction of precipitate identified $\mathrm{Fe}_{23}(\mathrm{C}, \mathrm{B})_{6}$ shown in Fig.9. (Steel B) 
果を示す。光学顕微鏡での析出物位置で炭素とボロンが検 出され，粒界の析出物は $\mathrm{Fe}_{23}(\mathrm{C}, \mathrm{B})_{6}$ であった。 $\mathrm{Fe}_{23}(\mathrm{C}, \mathrm{B})_{6}$ は 粒界上に板状に析出物し, どちらか片側のオーステナイト と K-S 関係を持ち，もう片側とは方位関係を必ずしも持た ない ${ }^{15)}$ 。 $\mathrm{Fe}_{23}(\mathrm{C}, \mathrm{B})$ ㅇ⽄出により周囲に発生した低炭素域と, 方位関係を持たない非整合界面側で優先的にフェライトが 生成し,パーライトの核となった可能性が考えられる。

以上より, ボロン添加による高温でのパーライト変態促 進は, 恒温保持中に析出した $\mathrm{Fe}_{23}(\mathrm{C}, \mathrm{B})_{6}$ が成長しパーライ 卜の核生成サイトとなっていたためと考えられる。

\section{$3 \cdot 3$ ノーズ温度以下での上部ベイナイト生成に及ぼすボロン の影響}

Fig. 11 に鋼種 $\mathrm{A}$ を $525^{\circ} \mathrm{C}$ で恒温変態途中に急冷を行った 際の, 旧オーステナイト粒界上に変態した初期の組織を示 す。上部べイナイト組織とパーライト組織は競合して生 成する。一部の上部べイナイト組織については単体の生成 が見られ，Fig.12に示すように，旧オーステナイト粒界に フェライトと共に生成している様子が観察された。この粒

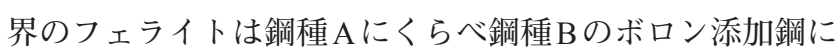
おいて観察された例が少なかった。EBSDを用いてBCCの IPF マップを採取 (40 nm ステップ) すると, 粒界のフェラ

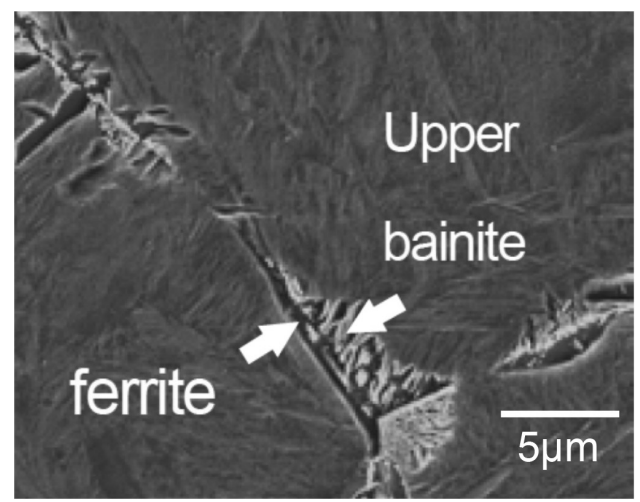

Fig. 11. Initial microstructure transformed at 525 degrees (Steel A).
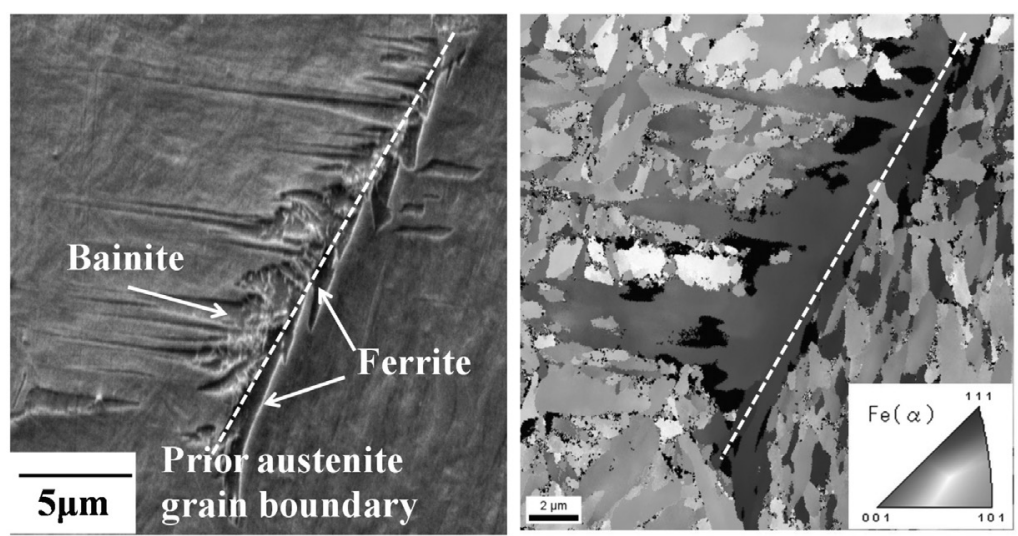

Fig. 12. Initial microstructure of transformation and IPF map. Observed bainite and ferrite microstructure had almost the same crystal orientation. (Steel A)
イトとベイナイトは同一の方位を持って生成していること が分かった。

そこで, 更に粒界のフェライトあるいは上部べイナイト と，旧オーステナイトとの結晶方位関係を確認した。オー ステナイト粒界を挟んで両側のフェライトと上部べイナイ 卜組織に対して，それぞれの近傍に存在する残留オーステ ナイトとの方位関係を確認した。上部ベイナイトとフェラ イトの極点図をFig.13に, 方位関係の模式図を Fig.14に示 す。フェライトの成長方向は K-S の方位関係を有し, べイ ライトが両側のオーステナイトに対してK-S関係に近い状 態で生成していることが判明した。一般的に，マルテンサ イトとオーステナイトは K-Sの方位関係を持つことが知ら れている。低炭素のフェライトーマルテンサイトの二相鋼 では, フェライトが生成した際にフェライトとマルテンサ

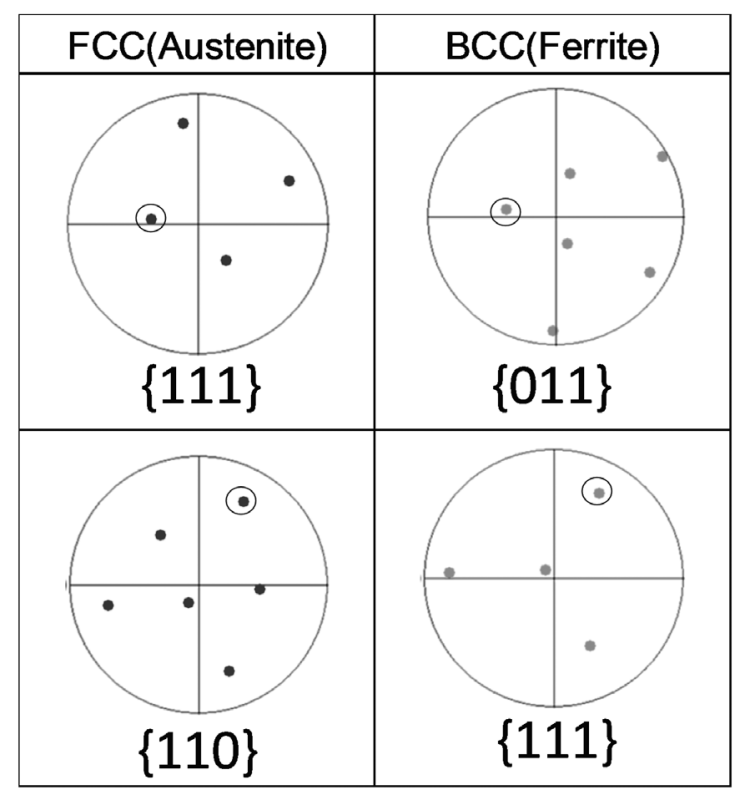

Fig. 13. Pole figures of ferrite (upper bainite) and austenite shown in Fig.12. Ferrite and austenite satisfied the near K-S relationship. ナイト側もオーステナイトとK-Sの方位関係に近く，フェ 
イトがK-Sの方位関係に近づくことが報告されており ${ }^{16)}$, フェライト Si添加した高炭素鋼の上部べイナイトに打い ても，オーステナイトとK-Sの方位関係を満たすフェライ トの存在下では，より核生成が促進されたと考えられる。

ボロンの添加により，粒界のフェライトが低減したこと から，ボロン添加による上部べイナイトの抑制メカニズム は，先行相となる粒界のフェライトが抑制されたことに起 因すると考えられる。

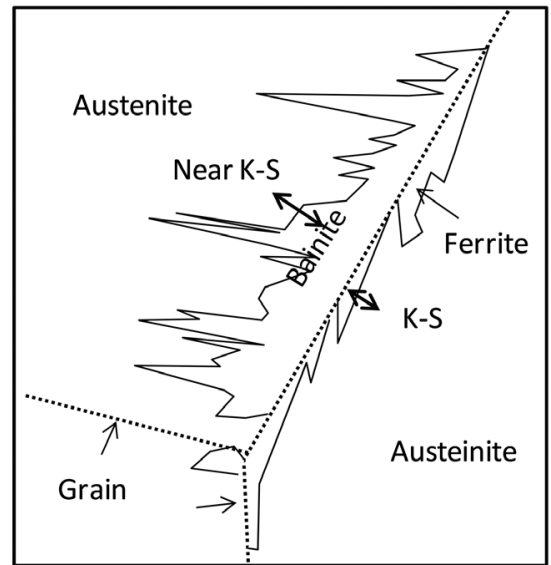

Fig. 14. Crystallographic orientation relationship between ferrite, upper bainite and ausitenite in Fig.12.

\section{$3 \cdot 4$ 上部ベイナイト生成に及ぼすボロンの存在状態}

Fig. 15 に鋼種Bを用いて, $1150^{\circ} \mathrm{C}$ でボロンを溶体化後, 急 冷したものと，一度 $690^{\circ} \mathrm{C}$ と $475^{\circ} \mathrm{C}$ に冷却後，それぞれ変態 させずに $200 \mathrm{~s}$ 保持したのち急冷したものの, ATE照射後の フィルムの観察写真をそれぞれ示す。コントラストが濃い 部分がボロンの存在位置である。溶体化後に急冷した条件 でもボロンは粒界上に偏析して存在しているのが分かる。 更に $200 \mathrm{~s}$ で恒温保持した条件では粒界部分のコントラス トが濃くなり，その傾向は析出ノーズに近い $690^{\circ} \mathrm{C} て ゙$ 顕著 であった。3・1項に示すように, $675^{\circ} \mathrm{C}$ 以上の保持では $\mathrm{Fe}_{23}$ $(\mathrm{C}, \mathrm{B}){ }_{6}$ が析出すると推定されるため, $690^{\circ} \mathrm{C}$ の濃いコントラ ストは $\mathrm{Fe}_{23}(\mathrm{C}, \mathrm{B})_{6}$ が析出した結果であると考えられる。一 方, $475^{\circ} \mathrm{C}$ では溶体化後急冷した場合のボロンの存在状態は 主に粒界偏析と考えられた。従って, Fig.2に示すように上 部ベイナイトの抑制に有効なボロンの存在状態は, 粒界偏 析である可能性が示された。更に, ベイナイト生成の抑制に 有効なボロンの存在状態が, 粒界偏析であるのか, $\mathrm{BN}, \mathrm{Fe}_{23}$ $(\mathrm{C}, \mathrm{B})_{6}$ であるのかを明確にするべく，前述の析出処理によ り恒温変態後の上部べイナイト組織率の変化を検証した。

Fig.16に鋼種 C Eをオーステナイト化後に $850^{\circ} \mathrm{C}$ で保持 する $\mathrm{BN}$ 析出処理を施したのち, $525^{\circ} \mathrm{C} て ゙$ 恒温変態させた際 の上部べイナイト組織率に及ぼす $\mathrm{BN}$ 析出処理時間への影 響を示す。更にFig.17に鋼種CとEをオーステナイト後に

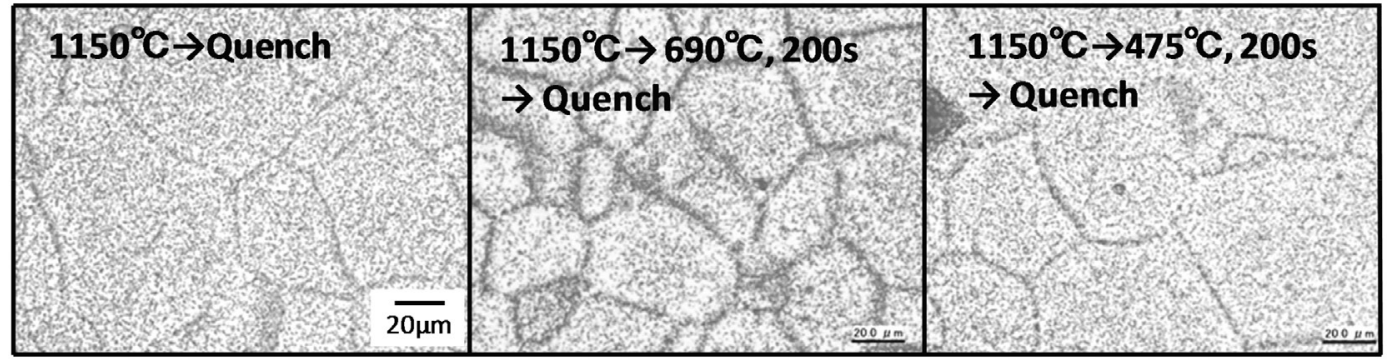

Fig. 15. ATE image of various thermal history. Dark contrast area shows presence of boron. (Steel B)

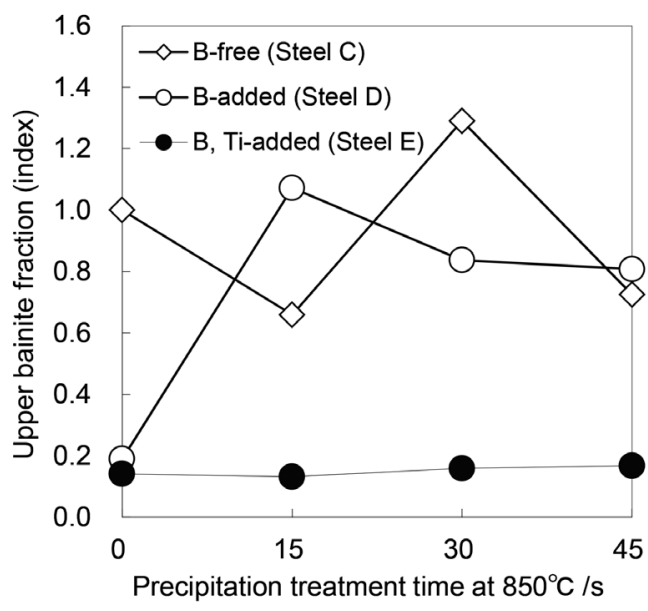

Fig. 16. Effect of isothermal holding time at $850^{\circ} \mathrm{C}$ on upper bainite fraction. (Steel C, Steel D and Steel E)

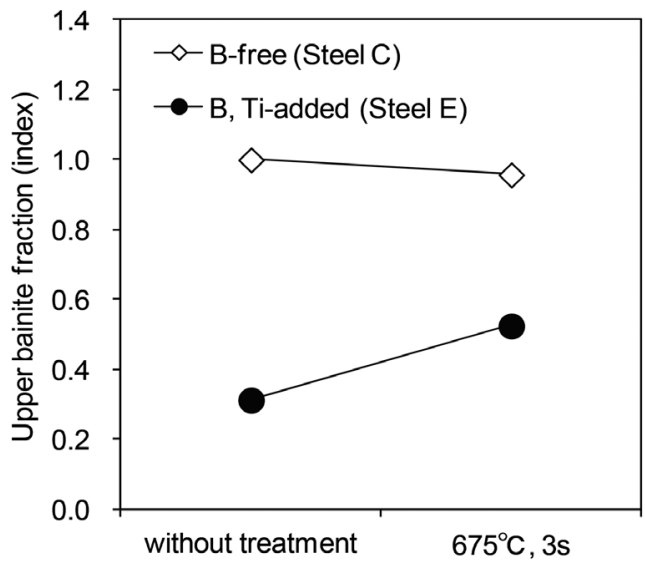

Fig. 17. Effect of $675^{\circ} \mathrm{C}$ isothermal holding treatment on upper bainite fraction. (Steel C, Steel E). 
$\mathrm{Fe}_{23}(\mathrm{C}, \mathrm{B})_{6}$ 析出処理を施したのち, $525^{\circ} \mathrm{C}$ で恒温変態させた 際の上部べイナイト組織率への影響を示す。いずれも鋼種 $\mathrm{C}$ を析出処理無く $525^{\circ} \mathrm{C}$ で恒温変態させた際の上部べイナ イト組織率との比で表した。ボロンを添加していない鋼種 $\mathrm{C}$ は $\mathrm{BN}, \mathrm{Fe}_{23}(\mathrm{C}, \mathrm{B}){ }_{6}$ 析出処理に関わらず上部べイナイト組 織率が高いのに対し, ボロンのみ添加した鋼種 D は BN 析 出処理により上部ベイナイト組織率が増加した。更に, ボ ロンと Tiを添加しNをTiNとして固定した鋼種Eについて は, BN析出処理では上部べイナイト組織率は変化しない が, $\mathrm{Fe}_{23}(\mathrm{C}, \mathrm{B}){ }_{6}$ 析出処理では上部べイナイトの組織率が増 加した。したがって，ボロンが $\mathrm{BN}$ あるいは $\mathrm{Fe}_{23}(\mathrm{C}, \mathrm{B})_{6}$ と いった析出状態となることで上部べイナイト抑制の効果が 低減することが判明し，粒界偏析したボロンが有効である ことが明らかとなった。

\section{4. 結言}

$\mathrm{Si}$ を添加した高炭素鋼へのボロン添加による恒温変態挙 動への影響を検証し，以下の結論を得た。

・ノーズ温度以上のパーライト変態に対しては, $650^{\circ} \mathrm{C}$ 以 上高温で $\mathrm{Fe}_{23}(\mathrm{C}, \mathrm{B}){ }_{6}$ が析出すると, パーライトの生成核 となりパーライト変態を促進する。 $625^{\circ} \mathrm{C}$ 以下で析出量 が少ない場合にはパーライト変態は抑制される。成長速 度やラメラー間隔に対しては影響がない。

・ノーズ温度以下では，上部べイナイト変態を抑制する。 $\mathrm{Si}$ 添加した高炭素鋼の上部べイナイトの生成は, 粒界に フェライトが生成し, そのフェライトを先行相として上
部ベイナイトが生成する場合が多い。ボロンはフェライ トを抑制する可能性が高い。

・上部ベイナイト抑制に有効なボロンの存在状態は, 粒界 偏析Bであり, ボロンが炭窒化物として析出すると効果 が低減する。

\section{文献}

1 ) T.Takahashi: Kinzoku, 66(1996), 19.

2 ) T.Takahashi, Y.Asano and M.Nagumo: Tetsu-to-Hagané, 62(1976), S368.

3 ) T.Takahashi, T.Tarui and S.Konno: JSSC Steel Constr. Eng., 1(1994), No.4, 119

4 ) T.Tarui, S.Nishida, A.Yoshie, H.Ohba M.Asano and I.Ochiai: Shinnittetsu Giho, 370(1999), 45.

5 ) I.Ochiai, S.Nishida, H.Ohba and A.Kawana: Tetsu-to-Hagané, 79(1993), 1101.

6 ) T.Manabe and S.Yamasaki: CAMP-ISIJ, 22(2009), 254, CD-ROM.

7 ) W.C.Leslie: The Physical Metallurgy of Steels, McGraw-Hill, New York, (1985).

8 ) M.Nagao, H.Yaguchi, N.Ibaraki and K.Ochiai: Tetsu-to-Hagané, 89(2003), 329

9 ) W.Y.Choo and C.M.Bae: ISIJ Int., 42(2002), Suppl., S47.

10) C.Mario and L.Andre: Wire J. Int., 40(2007), No.1, 96.

11) S.Nishida, S.Yamasaki, W.Yamada and K.Yamaguchi: CAMP-ISIJ, 21(2008), 1391, CD-ROM.

12) M.Tanino, H.Komatsu and S.Yi: Tetsu-to-Hagané, 67(1981), S1208.

13) R.A.Grange and J.B.Mitchell: Trans. Am. Soc. Met., 53(1959), 157.

14) K.Yamamoto, S.Matsuda, T.Mukai, H.Komatsu and Y.Ohno: Tetsuto-Hagané, 71(1985), S1513.

15) Ph.Maitrepierre, D.Thivellier and R.Tricot: Metall. Trans. A, 6(1975), 287.

16) S.Sakai, S.Morito, T.Ohba, Y.Yoshida and S.Takagi: Netsu Shori, 51(2011), 233 . 